\title{
A novel heteroplasmic mitochondrial DNA mutation, A8890G, in a patient with juvenile-onset metabolic syndrome: A case report
}

\author{
WEI YE ${ }^{1,2}$, SAIHUI CHEN $^{1}$, SHENG JIN ${ }^{1}$ and JIANXIN LU ${ }^{1,2}$ \\ ${ }^{1}$ Key Laboratory of Laboratory Medicine, Ministry of Education of China, \\ School of Laboratory Medicine and Life Science; ${ }^{2}$ Zhejiang Provincial Key Laboratory \\ of Medical Genetics, Wenzhou Medical University, Wenzhou, Zhejiang 325035, P.R. China
}

Received February 24, 2013; Accepted May 16, 2013

DOI: $10.3892 / \mathrm{mmr} .2013 .1616$

\begin{abstract}
Metabolic syndrome (MS) is a complex disorder characterized by a group of metabolic abnormalities. In the present study, the case of an 18-year-old male who presented with MS characteristics with central obesity (overweight and a waist circumference of $95 \mathrm{~cm}$ ) and dyslipidemia (high TG, low HDL levels and low apoA-I/apoB-100) was reported. The patient's family has maternally inherited diabetes and a number of the patient's maternal relatives present MS features. For the investigation of the mitochondrial DNA variants in the patient and the patient's family, genomic DNA of all the family members were extracted from peripheral blood using routine methods. Amplification of mitochondrial DNA in 24 overlapping fragments by PCR, direct sequencing and denaturing high-performance liquid chromatography was utilized for genetic analysis. Sequences were compared to the reference sequence to identify variants. Bioinformatic methods and databases were used to analyze conservation of the variants and to predict the protein secondary structure. With the exception of the patient, five relatives were diagnosed with MS. Moreover, 5 of the 8 family members had been diagnosed with diabetes, hearing loss and mild kidney impairment according to serum biochemical analysis. Further molecular genetic analysis indicated that the MS-associated variant T16189C was detected
\end{abstract}

Correspondence to: Professor Jianxin Lu, School of Laboratory Medicine and Life Science, Wenzhou Medical University, Tongxin Building, Room 313, Chashan University Town, Wenzhou, Zhejiang 325035, P.R. China

E-mail: jxlv313@gmail.com

Abbreviations: MS, metabolic syndrome; ATPase6, ATP synthase subunit 6; mtDNA, mitochondrial DNA; DHPLC, denaturing high-performance liquid chromatography; DBP, diastolic arterial blood pressure; SBP, systolic arterial blood pressure; FBG, fasting blood glucose; BUN, blood urine nitrogen; $\mathrm{Cr}$, creatine; UA, urine acid; Cys $\mathrm{C}$, cystine $\mathrm{C}$; HB, $\beta$-hydroxybutyric acid; TC, total cholesterol; TG, triglycerol; HDL-C, high-density lipoprotein cholesterol; LDL-C, low-density lipoprotein cholesterol

Key words: mitochondrial DNA, mutation, metabolic syndrome in this family. Notably, a heteroplasmic mutation A8890G was detected in the patient in the mitochondrial ATP6 gene, which codes the ATP synthase subunit 6 (ATPase6). A8890G changed the highly conserved ATPase6 Lys ${ }^{122}$ into Glu ${ }^{122}$ in the mitochondrial inner membrane. However, this mutation was not detected in other family members. In conclusion, the mutation A8890G may affect the function of ATPase 6 and the production of ATP, thus contributing to juvenile-onset MS. It was not detected in other family members possibly due to the mitochondrial genetic segregation or production of a new germline mutation in the juvenile-onset patient.

\section{Introduction}

Metabolic syndrome (1) is a complex disorder, characterized by a group of metabolic disorders, including hyperglycemia, hypertension, hyperlipaemia and central obesity, which are the risk factors of cardiovascular disease and diabetes. There is a high prevalence of MS in developed countries. According to the national health statistic reports issued in 2009 from the National Health and Nutrition Examination Survey 2003-2006, the prevalence of metabolic syndrome in the USA, is $34 \%$ in the population of 20 years of age. The prevalence of metabolic syndrome increased in different age groups for the two genders (2). However, in recent years, the prevalence of MS has increased at an alarming rate in developing countries and districts of Asia (3-5). According to the National Health and Nutrition Examination Survey 2003-2006, Chinese prevalence of MS (4) increased by $14-18 \%$ in 2005 and has continued to rise. Approximately $60-80 \%$ of diabetic patients are also MS patients.

An unhealthy lifestyle, including lack of physical exercise, bad nutritional habits, hormone changes and aging factors are associated with the onset of MS (6). However the two important risk factors for MS are central obesity and insulin resistance (7). Individuals with excess abdominal fat are more likely to develop hypertension and increased levels of blood cholesterol, triglycerides and fatty acids, which may affect insulin in glucose regulation (7) and lead to insulin resistance.

MS is caused by environmental and genetic factors. Previous studies have revealed numerous target molecules and variation associated with MS. Nuclear genes, including peroxisome proliferator-activated receptor- $\gamma$, lamin A/C gene 
Table I. Clinical and biochemical characteristics of all family members.

\begin{tabular}{|c|c|c|c|c|c|c|c|c|}
\hline \multirow{2}{*}{$\frac{\text { Variables }}{\text { General }}$} & \multicolumn{8}{|c|}{ Family members } \\
\hline & $\mathrm{I}_{2}$ & $\mathrm{II}_{1}$ & $\mathrm{II}_{4}$ & $\mathrm{II}_{5}$ & $\mathrm{II}_{6}$ & $\mathrm{III}_{1}$ & $\mathrm{III}_{2}$ & $\mathrm{III}_{3}$ \\
\hline Gender & $\mathrm{F}$ & M & $\mathrm{F}$ & M & $\mathrm{F}$ & $\mathrm{F}$ & $\mathrm{M}$ & M \\
\hline Age, years & 85 & 61 & 54 & 45 & 43 & 38 & 33 & 18 \\
\hline Waist circumstances, $\mathrm{cm}$ & 75 & 97 & 87 & 85 & 90 & 94 & 87 & 95 \\
\hline $\operatorname{BMI}\left(\mathrm{kg} / \mathrm{m}^{2}\right)$ & 20.02 & 28.08 & 24.30 & 21.45 & 26.35 & 27.34 & 21.71 & 27.47 \\
\hline $\mathrm{DBP}(\mathrm{mmHg})$ & 62 & 80 & 78 & 75 & 80 & 80 & 70 & 70 \\
\hline $\mathrm{SBP}(\mathrm{mmHg})$ & 120 & 130 & 126 & 130 & 120 & 130 & 110 & 110 \\
\hline History of diabetes, years & 10 & 10 & 4 & 1 & 1 & 0 & 0 & 0 \\
\hline \multicolumn{9}{|l|}{ Biochemical parameters } \\
\hline $\mathrm{FBG}(\mathrm{mmol} / \mathrm{l})$ & 4.8 & 7.78 & 5.17 & 6.98 & 10.78 & 5.87 & 5.08 & 5.08 \\
\hline HbA1c1 (\%) & 6.58 & 7.57 & 6.01 & 7.81 & 9.39 & 5.1 & 5.35 & 4.65 \\
\hline BUN (mmol/l) & 5.7 & 4.1 & 6.9 & 4.3 & 3.9 & 6.1 & 4.3 & 4 \\
\hline $\mathrm{Cr}(\mu \mathrm{mol} / \mathrm{l})$ & 65 & 75 & 81 & 60 & 40 & 50 & 54 & 51 \\
\hline $\mathrm{UA}(\mu \mathrm{mol} / \mathrm{l})$ & 447 & 346 & 409 & 307 & 214 & 288 & 230 & 342 \\
\hline Cys C (mg/l) & 1.41 & 1.32 & 1.57 & 1.28 & 0.68 & 1.20 & 1.09 & 1.29 \\
\hline $\mathrm{HB}(\mathrm{mmol} / \mathrm{l})$ & 0.07 & 0.06 & 0.07 & 0.05 & 0.12 & 0.09 & 0.06 & 0.07 \\
\hline \multicolumn{9}{|l|}{ Lipid parameters } \\
\hline $\mathrm{TC}(\mathrm{mmol} / \mathrm{l})$ & 4.15 & 4.24 & 4.58 & 7.33 & 5.01 & 6.29 & 4.54 & 6.78 \\
\hline TG (mmol/l) & 0.54 & 1.18 & 1.1 & 2.43 & 2.22 & 1.56 & 1.55 & 1.8 \\
\hline HDL-C (mmol/l) & 1.4 & 1.3 & 1.36 & 1.24 & 0.96 & 1.59 & 1.04 & 0.97 \\
\hline LDL-C (mmol/l) & 2.27 & 2.64 & 2.62 & 4.79 & 2.52 & 3.96 & 2.74 & 4.86 \\
\hline apoA-I (g/l) & 1.2 & 1.38 & 1.41 & 1.07 & 1.24 & 1.53 & 0.94 & 1.13 \\
\hline apoB-100 (g/l) & 0.98 & 1.15 & 1.13 & 1.62 & 1.11 & 1.29 & 0.93 & 2.14 \\
\hline apoA-I/apoB-100 & 1.22 & 1.2 & 1.25 & 0.66 & 1.12 & 1.19 & 1.01 & 0.53 \\
\hline \multirow[t]{2}{*}{ Hearing loss } & + & + & + & & & & & \\
\hline & & & (Single ear) & - & - & - & - & - \\
\hline
\end{tabular}

DBP, diastolic arterial blood pressure; SBP, systolic arterial blood pressure; FBG, fasting blood glucose; BUN, blood urine nitrogen; Cr, creatine; UA, urine acid; Cys C, cystine C; HB, $\beta$-hydroxybutyric acid; TC, total cholesterol; TG, triglycerol; HDL-C, high-density lipoprotein cholesterol; LDL-C, low-density lipoprotein cholesterol.

and IL-6, are considered as susceptibility genes of MS (8-12). Genetic factors, including mitochondrial DNA variants have also been associated with the onset of MS $(1,13,14)$.

Mitochondrial DNA (mtDNA) (15) contains 37 genes, including 2 ribosomal RNA genes, 22 transfer RNA genes and 13 coding genes, which code the proteins involved in oxidative phosphorylation. mtDNA has a higher mutation rate than nuclear DNA as it lacks protective histones and is susceptible to oxidative damage from reactive oxygen species (ROS) generated during respiration in the mitochondria (16). Studies have indicated that mitochondrial genetic defects may lead to $\beta$-cell dysfunction and insulin resistance (17). Moreover, mitochondrial dysfunction and biogenesis may be involved in the development of MS $(18,19)$.

In the present study, a juvenile-onset metabolic syndrome male with a maternally inherited diabetes family was examined. In the patient's family, a number of members diagnosed with type 2 diabetes also presented characteristics of MS, however, the 18-year-old male had not developed diabetes. Notably, a heteroplasmic mtDNA mutation, A8890G, observed in the male was not observed in other family members. The
A8890G is located in the ATPase 6 gene, which encodes for a subunit of ATP synthase (ATPase) in mitochondria. Therefore, it is hypothesized that A8890G may be associated with mitochondrial dysfunction and may contribute to juvenile-onset of MS.

\section{Materials and methods}

Subjects. A maternally inherited diabetes family was contacted through the Endocrinology Department and the Medical Examination Center of the First Affiliated Hospital of Wenzhou Medical College of Zhejiang Province in China and recruited. Peripheral blood samples were obtained from the patient and all participating family members. Serum triacylglycerol (TG), total cholesterol (TC), low-density lipoprotein (LDL), high-density lipoprotein (HDL), glucose, liver profile and kidney function parameters were determined using routine automated assay methods following an overnight fast.

Diagnosis of MS was determined according to the diagnostic criteria proposed by the International Diabetes Federation (IDF) in 2005 (6). Subjects were diagnosed with 
metabolic syndrome if they had a waist circumference of $>90 \mathrm{~cm}$ in males and $>80 \mathrm{~cm}$ in females and two or more of the following four components: i) serum triglycerides of $>1.7 \mathrm{mmol} / \mathrm{l}$ or having clinical treatment; ii) HDL-cholesterol levels $<0.9 \mathrm{mmol} / 1$ in males and $<1.0 \mathrm{mmol} / 1$ in females or having clinical treatment; iii) $\mathrm{BP}$ of $\geq 130 / 85 \mathrm{mmHg}$ or under anti-hypertensive treatment; iv) fasting glucose of $\geq 5.6 \mathrm{mmol} / 1$ or known treatment for diabetes. Subjects with $\leq 2$ risk components were excluded.

A total of 165 freshmen were recruited in Wenzhou Medical College and underwent a routine healthy check-up. The study was approved by the Hospital Ethics Committee. Informed consent was obtained from all participating subjects.

Mitochondrial DNA analysis. Genomic DNA was extracted from peripheral blood leukocytes of each individual using universal genomic DNA extraction kit version 3.0 (Takara Bio Inc., Shiga, Japan). Entire mitochondrial DNA was amplified in 24 overlapping fragments using primer sets, as described in a previous study (20).

PCR was performed at a final volume of $22 \mu \mathrm{l}$ as follows: $1.5 \mu \mathrm{l} \mathrm{MgCl}_{2}$ (25 mmol/l), $2.0 \mu \mathrm{l} \mathrm{dNTP}$ mixture $(2.5 \mathrm{mmol} / \mathrm{l}$ of each component), $2.0 \mu \mathrm{l} 10 \mathrm{X}$ Ex Taq buffer, $0.2 \mu \mathrm{l}$ of each primer $(10 \mu \mathrm{mol} / \mathrm{l}), 0.1 \mu \mathrm{l}$ Ex Taq polymerase (Takara Bio Inc.) and $2.0 \mu \mathrm{l}$ genomic DNA as the template. PCR was performed in a MyCycler Thermal Cycler 170-9703 (Bio-Rad, Hercules, CA, USA).

PCR conditions were as follows: initial denaturation at $94^{\circ} \mathrm{C}$ for $5 \mathrm{~min}$, followed by 35 cycles of denaturation at $94^{\circ} \mathrm{C}$ for $30 \mathrm{sec}$, annealing at $60^{\circ} \mathrm{C}$ for $45 \mathrm{sec}$ and extension at $72^{\circ} \mathrm{C}$ for $1 \mathrm{~min}$, with a final extension at $72^{\circ} \mathrm{C}$ for $6 \mathrm{~min}$. Amplification products were confirmed using electrophoresis in $1.2 \%$ agarose gels and visualized by staining with ethidium bromide. PCR products underwent direct sequencing in an ABI 3730 DNA sequencer (Sigma, St. Louis, MO, USA). Sample sequences were compared with the revised Cambridge Reference Sequence (rCRS) from Mitomap, a human mitochondrial genome database (http://www.mitomap.org).

Multiple amino acid sequence alignment was performed by Clustal X. The secondary structure of mitochondrial ATPase6 was predicted by the SOSUI system (http://bp.nuap.nagoya-u. ac.jp/sosui/sosui_submit.html).

Denaturing high-performance liquid chromatography (DHPLC) assay. PCR amplification of mtDNA mt 8702-8982 (281 bp) was performed at a final volume of $20 \mu \mathrm{l}$ as follows: $0.1 \mu 1$ Pyrobest DNA Polymerase (Takara Bio Inc.), $2.0 \mu 1$ 10X Pyrobest buffer (containing $\mathrm{Mg}^{2+}$ ), $3.0 \mu \mathrm{l} \mathrm{dNTP}$ mixture, $0.5 \mu \mathrm{l}$ of each primer (10 $\mu \mathrm{mol} / 1$, DHPLC grade), $2.0 \mu \mathrm{l}$ genomic DNA as template. The primer sequences used were: forward: 5'-CCATACACAACACTAAAGGACGAA-3' and reverse: 5'-TTGAATGAGTAGGCTGATGGTTT-3'. PCR conditions were as follows: an initial denaturation at $95^{\circ} \mathrm{C}$ for $5 \mathrm{~min}$, followed by 35 cycles of denaturation at $95^{\circ} \mathrm{C}$ for $10 \mathrm{sec}$, annealing at $60^{\circ} \mathrm{C}$ for $20 \mathrm{sec}$ and extension at $72^{\circ} \mathrm{C}$ for $45 \mathrm{sec}$, with a final extension at $72^{\circ} \mathrm{C}$ for $6 \mathrm{~min}$. PCR products were denatured at $95^{\circ} \mathrm{C}$ for $1 \mathrm{~min}$ and cooled to $4^{\circ} \mathrm{C}$ at a rate of $1^{\circ} \mathrm{C} / \mathrm{min}$ to allow for heteroduplex formation. The DHPLC assay was performed in a WAVE ${ }^{\circledR}$ nucleic acid fragment system (Transgenomic Inc., Omaha, NE, USA).

\section{Results}

Family and biochemical analysis. Clinical and biochemical characteristics of all the family members are provided in Table I. The patient details presented are of a typical maternally inherited diabetes family (Fig 1A).

According to the IDF MS diagnostic criteria $(21,22)$, the 18-year-old male (III3) was diagnosed with MS and other family members II1, II5, III6, III1 and III3 also presented MS features. Subjects I2, II1, II4, II5 and II6 suffered from diabetes for $>1$ year, with hearing loss and mild kidney impairment. Subjects II1, II6, III1 and III3 were overweight (BMI 25-29 kg/cm², Table I). No obesity $(B M I \geq 30)$ and hypertension was observed in the family. In addition, it was observed that the male patient (III3) and the patient's father (II5) presented lipid metabolism dysfunction with higher TG and LDL-C levels, lower HDL-C level and $<1.0$ of the ApoA-I/ApoB100 ratio (Table I).

mtDNA variant analysis. Mitochondrial genomic DNA variants in the family are provided in Table II. An MS-associated variant T16189C was observed in this family. Using sense-, antisense-sequencing and DHPLC analysis, a heteroplasmic A-G substitution at mt 8890 (Fig. 1B and C) was detected only in the 18-year-old male patient (III3). A8890G changed the basic amino acid Lys to Glu at position 122 of the ATPase6 subunit. This amino acid is located in the intermembrane of the mitochondria (Fig. 2) and is highly conserved in 30 species (Table III). In addition, there are numerous mtDNA variants, however A8890G was not observed on the mitochondrial ATPase 6 gene of the control subjects. No other MS or diabetes-associated mutations were detected in this patient or the patient's family.

\section{Discussion}

Although nuclear genes are involved in MS onset, mtDNA mutations are also significant in the development of MS. Mitochondrial tRNA ${ }^{\text {Ile }}$ T4291C mutation was first observed in a Caucasian population with MS where it was hypothesized to cause a cluster of metabolic defects. In addition, mtDNA D-loop T16189C was widely implicated in the development of insulin resistance, MS and coronary artery disease $(14,23)$. Subsequent studies confirmed that mutations in mtDNA were associated with diabetes, particularly, heteroplasmy tRNA ${ }^{\text {Leu(UUR) }}$ A $3243 \mathrm{G}$ was implicated in causing maternal-inherited diabetes (24-26). Extensive studies on the $\mathrm{A} 3243 \mathrm{G}$ mutation revealed inefficient aminoacylation, impairments in the processing of tRNA precursors and base post-transcriptional modification of tRNA ${ }^{\mathrm{Leu}(U U R)}$, which induced mitochondrial dysfunction (27-31).

In the present study, a juvenile-onset metabolic syndrome male in a maternally inherited diabetes family was examined. Although the family was a typical diabetic family, characteristics of MS with mild increasing cystine C levels, a sensitive marker for renal impairment, were also presented. The patient presented central obesity (overweight and $95 \mathrm{~cm}$ of waist circumference), dyslipidemia (high TG, low HDL level and low apoA-I/apoB-100) and mild renal impairment according to cystine $\mathrm{C}$ levels. Obesity is a risk factor for insulin resis- 
A

II

III

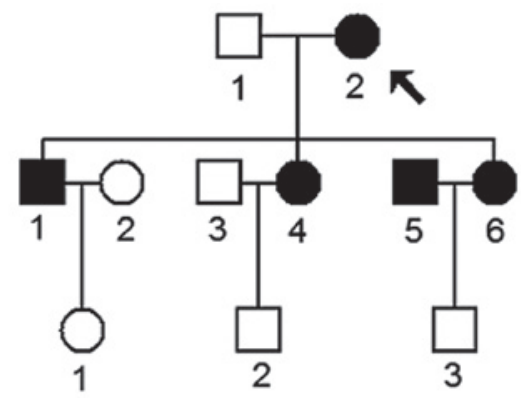

C

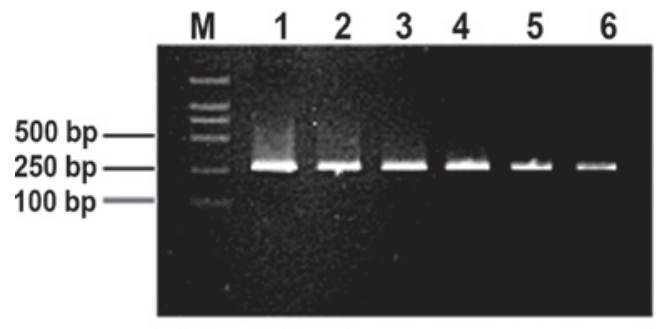

B

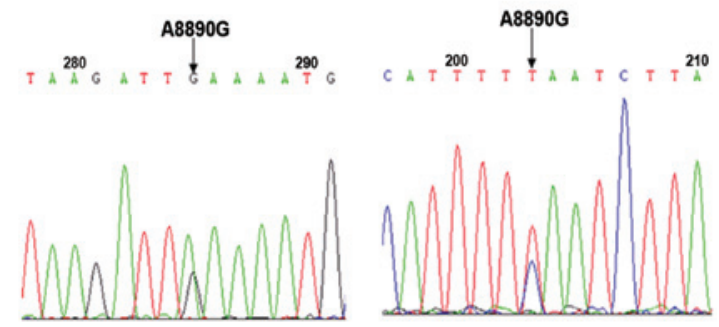

D

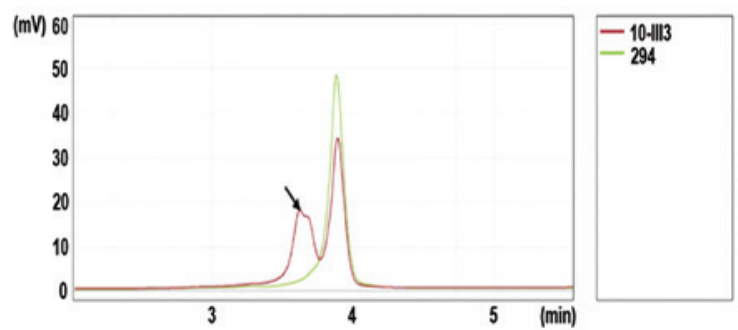

$\mathbf{E}$

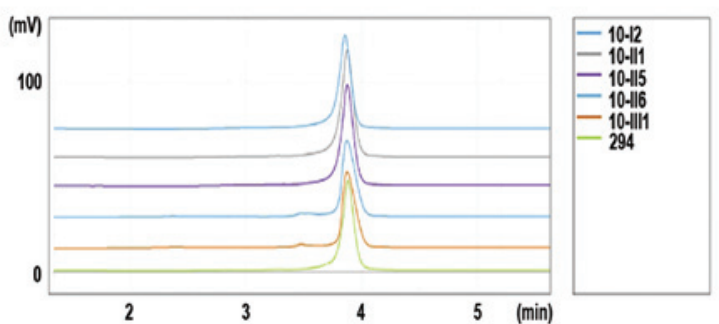

Figure 1. Pedigree chart and mtDNA analysis of the family. (A) Pedigree chart of the family. Arrow denotes proband. (B) A8890G mutation in III3 mitochondrial ATP6 gene. The left and right are sequencing and anti-sequencing results separately, the arrow denotes the variation site. (C) Agarose gel electrophoresis of PCR products (mt 8702-8982, 281 bp), M: DNA marker DL2000; lanes 1-6: PCR products 281 bp. (D) DHPLC analysis result of III3. Spectrum of III3 shows two peaks, the arrow denotes a heterologous double chain peak, the percentage of the peak area is 33.261 and $66.739 \%$, respectively; 10 -III 3 is the patient, 294 is the negative control. (E) DHPLC analysis results of other family members, 294 is the negative control.

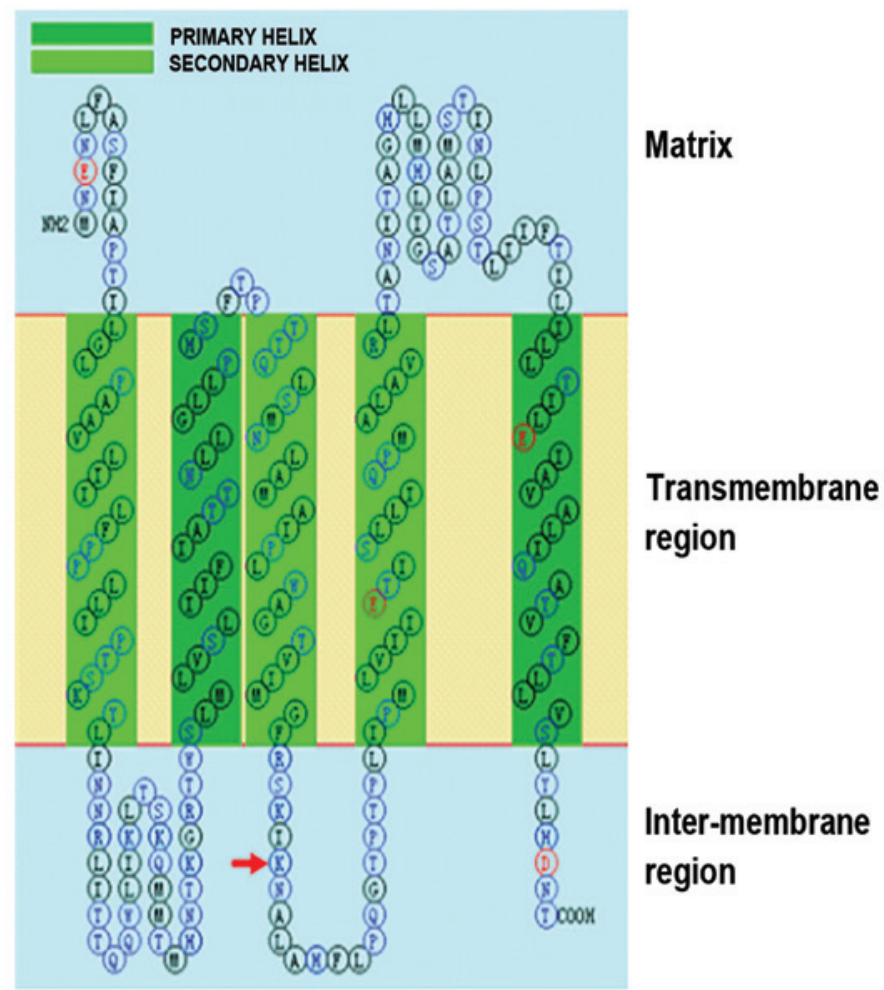

Figure 2. Secondary structure prediction of ATPase6. Arrow denotes Lys122 in inter-membrane region.(http://bp.nuap.nagoya-u.ac.jp/sosui/cgi-bin/adv_sosui.cgi). 
Table II. mtDNA variants in this family. ${ }^{\text {a }}$

\begin{tabular}{|c|c|c|c|c|c|}
\hline Gene & Position & $\begin{array}{l}\text { Nucleotide } \\
\text { replacement }\end{array}$ & $\begin{array}{l}\text { Amino } \\
\text { acid replacement }\end{array}$ & $\begin{array}{l}\text { Conservation } \\
(H / B / M / X)^{\mathrm{b}}\end{array}$ & $\begin{array}{l}\text { Previously } \\
\text { Reported }^{\mathrm{c}}\end{array}$ \\
\hline \multirow[t]{9}{*}{ D-Loop } & 73 & $A-G$ & & & Y \\
\hline & 263 & $A-G$ & & & $\mathrm{Y}$ \\
\hline & 315 & $\mathrm{C}-\mathrm{CC}$ & & & $\mathrm{Y}$ \\
\hline & 489 & $\mathrm{~T}-\mathrm{C}$ & & & $\mathrm{Y}$ \\
\hline & 16184 & C-T & & & $\mathrm{Y}$ \\
\hline & 16189 & $\mathrm{~T}-\mathrm{C}$ & & & $\mathrm{Y}$ \\
\hline & 16223 & C-T & & & $\mathrm{Y}$ \\
\hline & 16298 & $\mathrm{~T}-\mathrm{C}$ & & & $\mathrm{Y}$ \\
\hline & 16319 & $\mathrm{G}-\mathrm{A}$ & & & $\mathrm{Y}$ \\
\hline \multirow[t]{2}{*}{ 12S rRNA } & 750 & $A-G$ & & A/A/A/- & $\mathrm{Y}$ \\
\hline & 1438 & A-G & & $\mathrm{A} / \mathrm{A} / \mathrm{A} / \mathrm{G}$ & $\mathrm{Y}$ \\
\hline \multirow[t]{2}{*}{ 16S rRNA } & 2706 & $A-G$ & & $\mathrm{~A} / \mathrm{G} / \mathrm{A} / \mathrm{A}$ & $\mathrm{Y}$ \\
\hline & 2835 & C-T & & $\mathrm{C} / \mathrm{A} / \mathrm{A} / \mathrm{A}$ & $\mathrm{Y}$ \\
\hline \multirow[t]{2}{*}{ ND2 } & 4715 & $A-G$ & & & $\mathrm{Y}$ \\
\hline & 4769 & $A-G$ & & & $\mathrm{Y}$ \\
\hline \multirow[t]{3}{*}{$\mathrm{CO} 1$} & 6179 & G-A & & & $\mathrm{Y}$ \\
\hline & 7028 & $\mathrm{C}-\mathrm{T}$ & & & $\mathrm{Y}$ \\
\hline & 7196 & C-A & & & $\mathrm{Y}$ \\
\hline $\mathrm{CO} 2$ & 8245 & $A-G$ & & & $\mathrm{Y}$ \\
\hline \multirow[t]{3}{*}{ ATP6 } & 8860 & A-G & Thr-Ala & $\mathrm{T} / \mathrm{A} / \mathrm{A} / \mathrm{T}$ & $\mathrm{Y}$ \\
\hline & 8890 & $A-G$ & Lys-Glu & $\mathrm{K} / \mathrm{K} / \mathrm{K} / \mathrm{N}$ & $\mathrm{N}$ \\
\hline & 9053 & G-A & Ser-Asn & $\mathrm{S} / \mathrm{G} / \mathrm{G} / \mathrm{T}$ & $\mathrm{Y}$ \\
\hline $\mathrm{CO} 3$ & 9540 & $\mathrm{~T}-\mathrm{C}$ & & & $\mathrm{Y}$ \\
\hline \multirow[t]{2}{*}{ ND3 } & 10398 & $A-G$ & Thr-Ala & $\mathrm{T} / \mathrm{T} / \mathrm{T} / \mathrm{A}$ & $\mathrm{Y}$ \\
\hline & 10400 & C-T & & & $\mathrm{Y}$ \\
\hline \multirow[t]{3}{*}{ ND4 } & 10873 & $\mathrm{~T}-\mathrm{C}$ & & & $\mathrm{Y}$ \\
\hline & 11176 & $\mathrm{G}-\mathrm{A}$ & & & $\mathrm{Y}$ \\
\hline & 11719 & $\mathrm{G}-\mathrm{A}$ & & & $\mathrm{Y}$ \\
\hline ND5 & 12705 & C-T & & & $\mathrm{Y}$ \\
\hline ND6 & 14470 & $\mathrm{~T}-\mathrm{C}$ & & & $\mathrm{Y}$ \\
\hline \multirow[t]{4}{*}{ CytB } & 15043 & G-A & & & $\mathrm{Y}$ \\
\hline & 15301 & G-A & & & $\mathrm{Y}$ \\
\hline & 15326 & $A-G$ & Thr-Ala & $\mathrm{T} / \mathrm{M} / \mathrm{I} / \mathrm{I}$ & $\mathrm{Y}$ \\
\hline & 15487 & A-T & & $\mathrm{P} / \mathrm{P} / \mathrm{P} / \mathrm{P}$ & $\mathrm{Y}$ \\
\hline
\end{tabular}

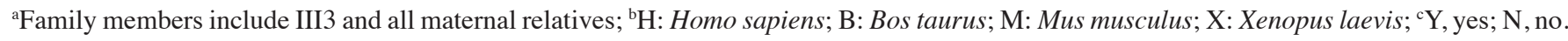

tance and pancreatic $\beta$-cells are likely to secrete more insulin when compensating for insulin resistance. The dysfunction of $\beta$-cells may cause pre-diabetes, a condition ultimately leading to diabetes (32).

Notably, the mtDNA genome assay detected a heteroplasmic mtDNA mutation A8890G in the patient and was not observed in other members of the family. In addition, MS-associated mitochondrial T16189C single-nucleotide polymorphism was detected in all the family members. No known diabetes or MS-associated mitochondrial mutations, including tRNA ${ }^{\mathrm{Leu}(\mathrm{UUR})} \mathrm{A} 3243 \mathrm{G}$ and $\mathrm{tRNA}^{\text {Ile }} \mathrm{T} 4291 \mathrm{C}$ (1), were detected.

A8890G is located in ATPase 6 gene, which encodes for a subunit of ATP synthase in mitochondria. ATPase is also known as mitochondrial respiratory chain complex V. It is a key enzyme in cell energy conversion, participating in the synthesis and hydrolysis of ATP. ATPase 6 is one of the ATPase subunits and is coded by the mitochondrial ATP6 gene. ATPase 6 is a component of the proton channel and is essential for proton transportation and energy production 
Table III. Amino acid in ATPase6 position 22 of 30 species.

\begin{tabular}{|c|c|c|c|c|c|}
\hline Species & Amino acid & Species & Amino acid & Species & Amino acid \\
\hline Gorilla gorilla & Lys & Bos taurus & Lys & Felis catus & Lys \\
\hline Pan paniscus & Lys & Ovis aries & Lys & Halichoerus grypus & Lys \\
\hline Pan troglodytes & Lys & Sus scrofa & Lys & Phoca vitulina & Lys \\
\hline Pongo pygmaeus & Lys & $\begin{array}{l}\text { Balaenoptera } \\
\text { musculus }\end{array}$ & Lys & $\begin{array}{l}\text { Canis } \\
\text { familiaris }\end{array}$ & Lys \\
\hline Hylobates lar & Lys & $\begin{array}{l}\text { Balaenoptera } \\
\text { physalus }\end{array}$ & Lys & $\begin{array}{l}\text { Artibeus } \\
\text { jamaicensis }\end{array}$ & Lys \\
\hline Papio hamadryas & Lys & $\begin{array}{l}\text { Hippopotamus } \\
\text { amphibius }\end{array}$ & Lys & $\begin{array}{l}\text { Dasypus } \\
\text { novemcinctus }\end{array}$ & Lys \\
\hline Equus caballus & Lys & $\begin{array}{l}\text { Mus } \\
\text { musculus }\end{array}$ & Lys & $\begin{array}{l}\text { Didelphis } \\
\text { virginiana }\end{array}$ & Lys \\
\hline Equus asinus & Lys & $\begin{array}{l}\text { Rattus } \\
\text { norvegicus }\end{array}$ & Lys & $\begin{array}{l}\text { Macropus } \\
\text { robustus }\end{array}$ & Lys \\
\hline Rhinoceros unicornis & Lys & $\begin{array}{l}\text { Myoxus } \\
\text { glis }\end{array}$ & Asn & $\begin{array}{l}\text { Ornithorhyncus } \\
\text { anatinus }\end{array}$ & Lys \\
\hline Ceratotherium simum & Lys & $\begin{array}{l}\text { Oryctolagus } \\
\text { cuniculus }\end{array}$ & Lys & $\begin{array}{l}\text { Xenopus } \\
\text { laevis }\end{array}$ & Asn \\
\hline
\end{tabular}

$(33,34)$. According to the mitomap database, http://mitomap. org, A8890G has not been previously reported. The majority of frequently reported mutations of ATPase 6 gene were heteroplasmic transversion T8993C and T8993G, which were associated with Leigh and NARP syndrome. Symptom severity was proportional to the heteroplasmy load (35-38). Cell and mitochondrial function analysis indicated that mutations led to energy deprivation, ROS overproduction and reduced ATP production (39-41).

Unlike T8993C/G (Leu156Pro/Arg), which changed an amino acid in the mitochondrial transmembrane protein, A8890G changed the amino acid in the mitochondrial intermembrane protein, which may affect the electrochemical proton gradient and energy production. These changes may contribute to the development of MS. Further evaluation of this abnormality is likely to include tissue biopsy, mitochondrial function tests and cell analysis.

This mutation was not detected in other family members, possibly as this mutation is a somatic mutation or a new germline mutation. Mitochondrial replicative segregation during cell division may affect the mutation (42). This indicates that the patient's mother (II6) may be a mosaic for this mutation. A low level of A8890G mutant mitochondria that cannot be detected using present analytical methods may be present in the patient's mother. At pre-ovulatory oocyte division, mutant and normal mitochondria segregate into next generation oocytes at random, producing uneven loading of mutant mitochondria. The patient may originate from an oocyte with a higher heteroplasmy rate.

In conclusion, the novel heteroplasmic A8890G may contribute to juvenile-onset MS. This mutation has not been detected in other family members, possibly as it is a somatic mutation or due to production of a new germline mutation or mitochondrial genetic segregation in the juvenile-onset patient.

\section{Acknowledgements}

Thanks for all the family members. This study is supported by the National Key Technology R\&D Program of China (Grant no. 2009BAI80B02); the Science Foundation of Zhejiang Province grants (nos. Y2090753, Y2100582); Zhejiang Provincial Education Department Research grant (no. Y200804470).

\section{References}

1. Wilson FH, Hariri A, Farhi A, et al: A cluster of metabolic defects caused by mutation in a mitochondrial tRNA. Science 306 : 1190-1194, 2004.

2. Ervin RB: Prevalence of metabolic syndrome among adults 20 years of age and over, by sex, age, race and ethnicity and body mass index: United States, 2003-2006. Natl Health Stat Report 5: $1-7,2009$.

3. Lim S, Shin H, Song JH, et al: Increasing prevalence of metabolic syndrome in Korea: the Korean National Health and Nutrition Examination Survey for 1998-2007. Diabetes Care 34: 1323-1328, 2011.

4. Gu D, Reynolds K, Wu X, et al: Prevalence of the metabolic syndrome and overweight among adults in China. Lancet 365: 1398-1405, 2005

5. Yi Z, Jing J, Liu X-Y, et al: Prevalence of the metabolic syndrome among rural original adults in NingXia, China. BMC Public Health 10: 140, 2010.

6. Alberti KG,Zimmet P and Shaw J; IDF Epidemiology Task Force Consensus Group: The metabolic syndrome - a new worldwide definition. Lancet 366: 1059-1062, 2005.

7. Janssen I, Katzmarzyk PT and Ross R: Waist circumference and not body mass index explains obesity-related health risk. Am J Clin Nutr 79: 379-384, 2004.

8. Ordovas JM: Nutrigenetics, plasma lipids and cardiovascular risk. J Am Diet Assoc 106: 1074-1081; quiz 1083, 2006. 
9. Frederiksen L, Brødbaek K, Fenger M, et al: Comment: studies of the Pro12Ala polymorphism of the PPAR-gamma gene in the Danish MONICA cohort: homozygosity of the Ala allele confers a decreased risk of the insulin resistance syndrome. J Clin Endocrinol Metab 87: 3989-3992, 2002.

10. Bennet AM, Prince JA, Fei GZ, et al: Interleukin-6 serum levels and genotypes influence the risk for myocardial infarction. Atherosclerosis 171: 359-367, 2003.

11. Murase Y, Yagi K, Katsuda Y, et al: An LMNA variant is associated with dyslipidemia and insulin resistance in the Japanese. Metabolism 51: 1017-1021, 2002.

12. Steinle NI, Kazlauskaite R, Imumorin IG, et al: Variation in the lamin A/C gene: associations with metabolic syndrome. Arterioscler Thromb Vasc Biol 24: 1708-1713, 2004.

13. Juo SH, Lu MY, Bai RK, et al: A common mitochondrial polymorphism 10398A $>\mathrm{G}$ is associated metabolic syndrome in a Chinese population. Mitochondrion 10: 294-299, 2010.

14. Palmieri VO, De Rasmo D, Signorile A, et al: T16189C mitochondrial DNA variant is associated with metabolic syndrome in Caucasian subjects. Nutrition 27: 773-777, 2011.

15. Anderson S, Bankier AT, Barrell BG, et al: Sequence and organization of the human mitochondrial genome. Nature 290 : 457-465, 1981

16. Yakes FM and Van Houten B: Mitochondrial DNA damage is more extensive and persists longer than nuclear DNA damage in human cells following oxidative stress. Proc Natl Acad Sci USA 94: 514-519, 1997.

17. Soejima A, Inoue K, Takai D, et al: Mitochondrial DNA is required for regulation of glucose-stimulated insulin secretion in a mouse pancreatic beta cell line, MIN6. J Biol Chem 271: 26194-26199, 1996.

18. Nishio Y, Kanazawa A, Nagai Y, et al: Regulation and role of the mitochondrial transcription factor in the diabetic rat heart. Ann NY Acad Sci 1011: 78-85, 2004

19. Nisoli E, Clementi E, Carruba MO, et al: Defective mitochondrial biogenesis: a hallmark of the high cardiovascular risk in the metabolic syndrome? Circ Res 100: 795-806, 2007.

20. Rieder MJ, Taylor SL, Tobe VO, et al: Automating the identification of DNA variations using quality-based fluorescence re-sequencing: analysis of the human mitochondrial genome. Nucleic Acids Res 26: 967-973, 1998.

21. Zimmet P, Alberti KG, Kaufman F, et al: The metabolic syndrome in children and adolescents. Lancet 370: 1541-1542, 2007.

22. Zimmet P, Alberti KG, Kaufman F, et al: The metabolic syndrome in children and adolescents-an IDF consensus report . Pediatr Diabetes 8: 299-306, 2007.

23. Mueller EE, Eder W, Ebner S, et al: The mitochondrial T16189C polymorphism is associated with coronary artery disease in Middle European populations. PLoS One 6: e16455, 2011.

24. van den Ouweland JM, Lemkes HH, Ruitenbeek W, et al: Mutation in mitochondrial tRNA(Leu)(UUR) gene in a large pedigree with maternally transmitted type II diabetes mellitus and deafness. Nat Genet 1: 368-371, 1992.

25. Ohkubo K, Yamano A, Nagashima M, et al: Mitochondrial gene mutations in the tRNA(Leu(UUR)) region and diabetes: prevalence and clinical phenotypes in Japan. Clin Chem 47: 1641-1648, 2001.

26. Maassen JA, 'T Hart LM, Van Essen E, et al: Mitochondrial diabetes: molecular mechanisms and clinical presentation. Diabetes 53 (Suppl 1): S103-S109, 2004.
27. Rossmanith W and Karwan RM: Impairment of tRNA processing by point mutations in mitochondrial tRNA(Leu)(UUR) associated with mitochondrial diseases. FEBS Lett 433: 269-274, 1998.

28. Janssen GM, Maassen JA and van Den Ouweland JM: The diabetes-associated 3243 mutation in the mitochondrial tRNA(Leu(UUR) gene causes severe mitochondrial dysfunction without a strong decrease in protein synthesis rate. J Biol Chem 274: 29744-29748, 1999.

29. Chomyn A, Enriquez JA, Micol V, et al: The mitochondrial myopathy, encephalopathy, lactic acidosis and stroke-like episode syndrome-associated human mitochondrial tRNALeu(UUR) mutation causes aminoacylation deficiency and concomitant reduced association of mRNA with ribosomes. J Biol Chem 275 19198-19209, 2000.

30. Yasukawa T, Suzuki T, Ueda T, et al: Modification defect at anticodon wobble nucleotide of mitochondrial tRNAs(Leu) (UUR) with pathogenic mutations of mitochondrial myopathy, encephalopathy, lactic acidosis and stroke-like episodes. J Biol Chem 275: 4251-4257, 2000.

31. Park H, Davidson E and King MP: The pathogenic A3243G mutation in human mitochondrial tRNALeu(UUR) decreases the efficiency of aminoacylation. Biochemistry 42: 958-964, 2003.

32. Lee JM: Why young adults hold the key to assessing the obesity epidemic in children. Arch Pediatr Adolesc Med 162: 682-687, 2008.

33. Hutcheon ML, Duncan TM, Ngai H, et al: Energy-driven subunit rotation at the interface between subunit a and the coligomer in the $\mathrm{F}(\mathrm{O})$ sector of Escherichia coli ATP synthase. Proc Natl Acad Sci USA 98: 8519-8524, 2001

34. Stock D, Leslie AG and Walker JE: Molecular architecture of the rotary motor in ATP synthase. Science 286: 1700-1705, 1999.

35. Baracca A, Sgarbi G, Mattiazzi M, et al: Biochemical phenotypes associated with the mitochondrial ATP6 gene mutations at nt8993. Biochim Biophys Acta 1767: 913-919, 2007.

36. Santorelli FM, Tanji K, Shanske S, et al: Heterogeneous clinical presentation of the mtDNA NARP/T8993G mutation. Neurology 49: 270-273, 1997

37. Takahashi S, Makita Y, Oki J, et al: De novo mtDNA nt 8993 $(\mathrm{T} \rightarrow \mathrm{G})$ mutation resulting in Leigh syndrome. Am J Hum Genet 62: 717-719, 1998

38. Tatuch Y, Christodoulou J, Feigenbaum A, et al: Heteroplasmic mtDNA mutation $(T \rightarrow G)$ at 8993 can cause Leigh disease when the percentage of abnormal mtDNA is high. Am J Hum Genet 50: 852-858, 1992 .

39. Mattiazzi M, Vijayvergiya C, Gajewski CD, et al: The mtDNA T8993G (NARP) mutation results in an impairment of oxidative phosphorylation that can be improved by antioxidants. Hum Mol Genet 13: 869-879, 2004.

40. Sgarbi G, Baracca A, Lenaz G, et al: Inefficient coupling between proton transport and ATP synthesis may be the pathogenic mechanism for NARP and Leigh syndrome resulting from the T8993G mutation in mtDNA. Biochem J 395: 493-500, 2006

41. Tatuch Y and Robinson BH: The mitochondrial DNA mutation at 8993 associated with NARP slows the rate of ATP synthesis in isolated lymphoblast mitochondria. Biochem Biophys Res Commun 192: 124-128, 1993.

42. Shoubridge EA: Mitochondrial DNA segregation in the developing embryo. Hum Reprod 15 (Suppl 2): S229-S234, 2000. 